\title{
Müslüman Dünyanın Bir Sorun Alanı Olarak Doğu Türkistan Meselesi ve Çin Halk Cumhuriyeti'nin İzlediği Politikalar
}

The Issue of the East Turkestan as A Problem Area of the Muslim World and Policies of the People's Republic of China

\section{Yusuf SAYIN, Gamze KOÇAK}

Siyaset Bilimi ve Uluslararası Ilişkiler Bölümü, Karamanoğlu Mehmetbey Üniversitesi, Karaman, Türkiye

Siyaset Bilimi ve Kamu Yönetimi Bölümü, Karamanoğlu Mehmetbey Üniversitesi, Karaman, Türkiye

\section{Özet}

Çalışmanın temel konusu, Çin'in, beş özerk bölgesinden birisi olan Şincan (Xinjian) Uygur Özerk Bölgesi üzerinde, uygulamakta olduğu politikaların araştırılması ve Türkiye'nin bu konuya bakış açııının tespit edilmesidir. Bu çerçevede Doğu Türkistan'ın sahip olduğu coğrafik konum, sosyal ve idari yapı irdelenmiş; Çin'in bu bölgede uygulamakta olduğu baskı politikası ayrıntılı bir şekilde ele alınmaya çalışılmıştır. Bu çalışmada temel amaç; Çin'in Doğu Türkistan halkına yönelik izlediği nüfus, göç, eğitim ve ekonomi politikaları gibi temel alanlarda işlediği hak ihlallerinin incelenmesi ve Türkiye'nin Doğu Türkistan'a dair izlediği dış politikayı ele almaktır. Türkiye'nin komşu ülkeler üzerinde uygulamak istediği 'sıfır sorun' söylemi Doğu Türkistan için çok etkili olmamış; Çin Halk Cumhuriyeti'nin Uygur Türkleri üzerinde uyguladığı baskı ve şiddet içerikli tavrına karşın Türkiye'nin sadece arabulucu olma rolünü üstlendiği görülmüştür. Türkiye'nin bu sorunu insani olarak görmesinin, Çin'in uyguladığı politikalarını gözden geçirmesine yardımcı olacağı ifade edilebilir. Çalışmada betimleyici araştırma yöntemi çerçevesinde konuyla ilgili birincil ve ikincil kaynaklardan faydalanılmıştır.

Anahtar Kelimeler: Çin Halk Cumhuriyeti (ÇHC), Doğu Türkistan Sorunu, Hak ihlalleri, Türkiye

\section{Abstract}

The main problem of the study is to research the policies that China applies on the Xinjian Uygur Autonomous Region, which is one of the five autonomous regions, and to determine Turkey's point of view on this issue. Within this problematic framework, it has been examined the geographic position and the social and administrative structure of the East Turkestan; the pressure policy that China is implementing in this region has been tried to elaborate. The main purpose of this study is to examine the violations of rights that China follows in the core areas such as population, migration, education and economic policies against the people of the East Turkestan and to treat the foreign policy of Turkey towards the East Turkestan. The 'zero problem' discourse, which Turkey wants to implement on its neighboring countries, has not been very effective for the East Turkestan; Turkey has been seen to have only a mediator role against the manner in pressure and violence of the People's Republic of China that imposes on the Uighur Turks. It can be argued that Turkey sees this issue as humanitarian view will help China to oversee its policies that it implements. In the study, the study has benefited from relevant primary and secondary sources within the context of the descriptive research methodology.

Keywords: People's Republic of China, The Issue of the East Turkestan, Violations of Right, Turkey.

CONTACT : Yusuf SAYIN, yusuf.sayin@hotmail.com.tr

Geliş Tarihi : 16.12.2016

Kabul Tarihi : 12.01.2017 


\section{Giriş}

1955 yılında Çin Halk Cumhuriyeti (ÇHC) yönetimini ele geçirmiş olan Komünist rejim tarafından kurulan Xinjian Uygur Özerk Bölgesi günümüze kadarki süreçte ÇHC'ye bağlı beş otonom yapıdan biridir. Resmi kaynaklarda "Şincan" (Xīnjiāng) olarak geçmektedir. Bununla birlikte Türkiye ve Türki Cumhuriyetlerde "Doğu Türkistan" olarak bilinmekte ve anılmaktadır. Günümüzde Şincan Uygur Özerk Bölgesi eyaletine bağlı bulunan Uygur Türkleri siyasi nedenlerden ötürü ayaklanma girişimlerinde bulunmuşlar; Uygur Türklerine karşı Çin'in sert asimilasyon politikaları gündeme gelmiştir. Fakat konu uluslararası arenada yeterince ilgi görememiştir.

Rusya ve Çin arasında kalan geniş topraklar Türkistan sınırları içinde kaldığından, dönemsel olarak çeşitli politik çekişmelere sahne olmuştur. Bu çekişmeler hegemonik anlamda birinin diğerinden üstün olduğu gösterilmek üzere gündeme gelmiştir. Doğal kaynakları sömürülen ve çeşitli hak ihlallerine maruz kalan Doğu Türkistan, bugün jeopolitik konumu itibarıyla üzerinde ekonomik çıkarlar gözeten Çin'in hâkimiyeti altında bulunmaktadır. ÇHC bu toprakların asıl sahibinin Uygur Türklerinin olduğunu görmezden gelerek günümüzde Han Çinlisi göçmenlerini bu bölgeye yerleştirip demografik yapıyı değiştirmeyi amaçlamaktadır.

$\mathrm{Bu}$ çalışmanın konusu, hala ÇHC'nin egemenliği altında bulunan ve uluslararası arenadan hak ettiği desteği bir türlü göremeyen "Doğu Türkistan" meselesidir. Çalışmanın amacı, Doğu Türkistan bölgesinin jeopolitik özelliği, stratejik önemi ve demografik yapısının incelemek; Çin'in Uygur Özerk Bölgesi üzerinde uyguladığı baskı ve şiddet içerikli tavrına karşılık, başta Türkiye olmak üzere, uluslararası toplumun ilgisi ve bölgede yaşanan hak ihlallerine karşılık Türkiye'nin gösterdiği dış politika davranışının ele almaktır.

\section{Doğu Türkistan (Şincan Uygur Özerk Bölgesi)}

Tarih boyunca üzerinde çeşitli hanedanlıklar kurulan Doğu Türkistan'ı Mançuların kurmuş olduğu Qing Hanedanı'na değinildiğinde; 1877 yılında Çin-Mançu istilasından sonra Çin, 1884 yılında Doğu Türkistan'ın vilayetlerine kendi askerlerini, memurlarını yerleştirmekle kalmayıp bölgeye 'Yeni Toprak' anlamına gelen aynı zamanda kendi içinde bir çelişki oluşturan "Şincan" adını vermiştir. Dolayısıyla akıllara şöyle bir soru gelmektedir: Çin Doğu Türkistan'ı kendi toprakları arasında kabul ediyorsa, neden Şincan adını vermiştir? Fakat 1884 yılından sonra Çin yönetimi Doğu Türkistan adının kullanımını yasaklamıştır (Zenginoğlu, 2013: 22; Özönder, 1998: 13;).

\subsection{Bölgenin Jeopolitik Özelliği}

Siyasi literatürde 'Orta Asya' olarak geçen Türkistan'ın kaynaklarda üç ana bölgeye ayrılmış olduğu görülmektedir. Birinci bölge olan Doğu Türkistan Büyük Türkistan'ın doğusunda ve Asya kıtasının tam ortasında yer almaktadır. Yüzölçümü kaynaklarda 1.828.418 kilometrekare olarak geçen alanda 30 milyon civarında Türkün yaşadığ belirtilmektedir. Aynı zamanda bu nüfusun çoğunun Orta Asya (Türkistan) kökenli olduğu da bilinmektedir (Uygur, Özbek, Kazak, Tatar ve Kırgız) (Gül, 2007: 252; Zenginoğlu, 2013: 23). İkinci bölge; Afganistan'ın kuzey bölümü olan Güney Türkistan'dır. Yine çeşitli kaynaklarda bu bölgede 5 milyondan fazla Özbek ve Türkmen Türklerinin yaşadığı belirtilmektedir. Üçüncü bölgenin ise üzerinde çeşitli Türk 
Cumhuriyetleri bulunan (Kazakistan, Kırgizistan, Tacikistan, Özbekistan, Türkmenistan) ve 55 milyon insanın yaşamakta olduğu belirtilen Batı Türkistan olduğu görülmektedir (Aynural ve Kesici, 2005: 1211). Çin resmi kaynaklarında Şincan/Xinjiang Uygur Özerk Bölgesi olarak geçmekte olan Doğu Türkistan coğrafi olarak ÇHC'nin kuzeybatı yönünde bulunmakta olup, tarihin ilk dönemlerinden bu yana 'Türklerin ana vatanı' ve Türk kültürünün beşiği konumundadır (İHH, 2016; Özönder, 1998: 11; Hayit, 2004; Togan, 1981).

\subsection{Bölgenin Stratejik Önemi}

Uygur azınlıklarının yaşamakta olduğu Şincan Uygur Özerk Bölgesi'nin yeraltı zenginlikleri ve konumu itibariyle stratejik öneme sahip olduğu görülmektedir (Dağc1 ve Keskin, 2013: 16). Geniş toprakları ve zengin doğal kaynaklara sahip olduğu bilinmekte olan Doğu Türkistan, 'Avrasya'nın kalbi' denilecek kadar önemli olduğu ifade edilebilir. Uygur bölgesi, Çin topraklarının altıda biri olduğu gibi, sekiz ülkeye de sınırı bulunmaktadır. Bu sebeple tarihsel açıdan bakılacak olursa, Uygur bölgesi Çin için yabancıların istilalarına karşı bir tampon görevi üstlendiği ifade edilebilir (Şen, 2009: 125, İHH, 2015 ).

Çin'in Batı ile iletişiminin gerçekleşmesi açısından ise iki temel engelin var olduğu söylenebilir. Bunlardan birincisi Taklamakan Çölü; bir diğeri ise Çin Seddi' dir. ÇHC'nin bu iki engel sebebiyle Batı ile olan iletişimini Doğu Türkistan üzerinden gerçekleştiği görülmektedir. Bu sebeple Doğu Türkistan, Çin için stratejik açıdan da oldukça önemlidir (Zenginoğlu, 2013: 22).

Çin'in bölgeye bu denli önem vermesinin bir diğer sebebi ise, Çin ekonomisinin büyük bir çoğunluğunu oluşturmakta olan Doğu Türkistan'ın temel hammadde sağlayıcısı konumunda olmasıdır. Doğu Türkistan'ın doğal kaynaklarını kullanmakta olan Çin'in uranyum, doğalgaz ve petrol gibi değerli enerji kaynaklarının kullanımının her açıdan Çin devletinin tekelinde olduğu görülmektedir (THE, 2016, İHH, 2015). Bölge sahip olduğu enerji kaynakları kadar birçok değerli madenle de gündeme gelmekte; alanda 118 ayrı maden çeşidi tespit edilmiş olup, yalnızca 30'unun işlenmekte olduğu belirtilmektedir (Dağcı ve Keskin, 2013: 15).

Toprakları içinde en az 56 etnik grup barındıran Çin'in üniter yapısının bütünleşmesinde Uygur Özerk Bölgesi kritik bir noktadadır. Burada meydana gelebilecek ayrılıkçı bir hareketin diğer etnik grupları da tetikleyeceği düşünülmekte, bunun da ülkeyi bir kargaşaya sürükleyeceği vurgulanmaktadır (İHH, 2015). Doğu Türkistan, Çin ile Avrupa yolu üzerinde olan İpek yolu karayolunun Çin'i Sibirya'ya, Rusya'ya ve Orta Doğu'ya bağlayan yolların kavşağında bulunması sebebiyle, hem bölgesel hem de küresel bir öneme sahip olduğu görülmektedir (Şen, 2009: 125). Çin' in tarihi İpek yolu üzerinde stratejik çıkarlarının olduğu bilinmekte ve bu sebeple Türkiye ile yeni İpek yolu projelerinin geliştirilmesini istemektedir. Örneğin; Nisan 2000' de Çin Devlet Başkanı olan Jiang Zemin, Türkiye'ye yapmış olduğu ziyarette, İpek yolunun iki millet arasında bir 'köprü', dışarıya açılan bir 'kapı' ve bir vücudun 'yumuşak karın bölgesi' olduğunu dile getirmiştir (Ekrem, 2012: 37). 


\subsection{Bölgenin Demografik Yapısı}

İşgalden sonra Çin Yönetimi, Doğu Türkistan topraklarına düzenli bir şekilde Çin vatandaşı yerleştirmeye başlamıştır. Bu düzenli zorunlu nüfus göçünün asıl sebebi ise geçmişten bu yana Türklere ait olan bölgenin demografik yapısını değiştirmek ve bölgeyi tamamıyla Çin Devleti'nin yönetimine bırakmaktır (THE, 2016).

Çin, bölgenin Uygur nüfusunu azaltarak onları azınlık durumuna getirmeyi amaçlamaktadır ve en önemli sorunlardan biri olan Han Çinlisi göçmenlerini Doğu Türkistan'a yerleştirmektedir. Bölgedeki Han Çinlisi göçmenlerini artırmadaki bir diğer etken ise Doğu Türkistan bölgesindeki Sovyet etkileridir. Sovyetlerin bölgedeki yeraltı ve yerüstü doğal kaynaklarından faydalanmak istemesi, Çin'in bölgede nüfusu artırıcı politikalar uygulamasını sağlamaktadır (Dağcı ve Keskin, 2013: 16; THE,2016).

Açılanan demografik rakamlar ise gerçekleri tam olarak bilinmemekle birlikte birbirleriyle çelişkili olduğu da görülmektedir. Çin makamlarının Doğu Türkistan nüfusunu bu şekilde tutarsız göstermelerinin iki sebebi olabilir: Ya azınlık nüfusu az gösterip onların haklarını vermemek ya da bölgenin yarısının Çin nüfusuyla kaplı olduğunu göstermektir (Tanay, 2016).

Çok kesin rakamlar olmamakla birlikte 1944 yılında Doğu Türkistan'ın Uygur nüfusu 3 milyona yakın iken, Çinli nüfus 200 binin üzerinde, diğer azınlıkların nüfusu ise 700 binden fazladır. Çin ile Uygur nüfusunun eşitlenmiş olduğu düşünüldüğünde, bunun sebebinin Çin hükümetinin uygulamış olduğu zorunlu göç politikasından kaynaklandığı ifade edilebilir Abdülhakim Selçuk'a göre 1923-2016 arası bölge nüfusu 45 milyon olması gerekirken 35 milyon civarında olduğu tahmin edilmektedir. Şincan Uygur Özerk Bölgesinin başkenti olan Urumçi'de ise 14 milyon civarında nüfus olduğu tahmin edilmekle birlikte bunun 12 milyon 750'si Han Çinlisi, 1 milyon 250'si ise Uygur Türkü olduğu tahmin edilmektedir. ${ }^{1}$

ÇHC bölgede güvenli bir şekilde hâkimiyet kurabilmek için nüfus yapısına ilişkin olarak zorunlu kürtaj ve kadınları kısırlaştırma metodu uygulamaktadır. Yapılan mülakatta kırda 2, şehirde ise 1 çocuk şartı getirildiği belirtilmektedir. Mahalle aralarına Çin'in yerleştirmiş olduğu insanlar, kadınların 8 aylık hamile olduğunu öğrenseler bile Çin yönetimine bildirmektedir. Bölgede yaşayan halk bu yasakları aşarsa çok ağır ekonomik cezalara çarptırılmakta; özellikle kırsal kesimlerde yaşayan köylü kadınlar sağlıklı olmayan ortamlarda zorunlu kürtaj işlemlerine tabi tutulmaktadır (Zenginoğlu, 2013: 23; Gökbayrak, 2016).

\section{Doğu Türkistan Sorunu}

Doğu Türkistan sorunu aslında bir Çin sorunudur, lakin bölge etnik, kültürel ve tarihsel bağlamda Türkiye'nin de ilgi alanına girmektedir. Ülkemizi ilgilendiren temel nokta; etnik ve insani açıdan bakıldığında Uygur Türkleridir, fakat Çin, Uygur Türklerinin bağımsızlık istemesi ve haklarına sahip olabilme meselesini Doğu Türkistan meselesi ile aynı konu olarak görmektedir. Doğu Türkistan sorununun temelinde din ya

\footnotetext{
${ }^{1}$ Çalışmanın bu kısmının oluşturulmasında Gökbayrak Dergisi Genel Sekreteri Abdülhakim Selçuk ile gerçekleştirilen görüşmeden yararlanılmıştır. Çalışmada, Genel Sekreter ile gerçekleştirilen görüşme kısaca "yapılan mülakatta" şeklinde ifade edilmektedir.
} 
da inanç farklılıklarının yattığı ön ifade edilse de aslında arka planında tamamıyla jeopolitik konum, sahip olduğu doğal kaynaklar ve en önemlisi Taklamakan Çölü ve Çin Seddi olduğu söylenir. Çin Seddi, Çin'in dış dünya ile bağlantısını kopardığı gibi aynı zamanda ülkeyi büyük bir ekonomik krize sokan etmenler arasında gösterilmektedir. Coğrafi olarak Doğu Türkistan ise bu iki önemli etmenin dışında kaldığı için ÇHC, Doğu Türkistan'ı, 'dışarıya açılan kapı' olarak görmektedir. Çin gibi büyük bir sanayisi ve pazarı olan ülkenin önemli derecede işçi gücü ve enerji kaynağına ihtiyacı var olduğu kabul edildiğinde (Şen, 2009: 125; Ekrem, 2012: 49; Deli, 2016), kaynağa olan ihtiyacını Doğu Türkistan üzerinden gidermeyi istediğini söylemek yanlış olmayacaktır.

\section{1. Çin'in Doğu Türkistan Politikası}

Çin, Doğu Türkistan'ı elden çıkarmak istememekte; sosyo-kültürel ve etnik yapısını plânlı bir şekilde değiştirmeye arzulamaktadır. Doğu Türkistan ise "cahil bırakarak ezip yok etme" politikasına karşı yaşadığı güçlüklere rağmen mücadelesini sürdürmektedir. 1949 yılından beri sistemli bir şekilde Doğu Türkistan üzerinde uygulanan politikalar arasında, 1949 yılında ÇHC'nin kurulmasıyla Şincan'a karşı olan ayrılıkçı eğilimleri azaltmak ve toprak bütünlüğünü güçlendirmek yer almaktadır. 1950'li yıllardan itibaren uygulamaya koyulan nüfus transferiyle bölgede Çinlilerin nüfusunda artış kaydedilmiş ve hoşgörü politikasından vazgeçilerek asimilasyonist bir politika izlenmeye ve zorla kültürel homojenleştirmeye başlanmıştır. 1960'll yıllardan itibarense bölgede üst üste nükleer denemeler yapılmıştır. Bu durum orta ve uzun vadede onarılamayacak sonuçlar doğurmuştur. 1964-1996 arası 46 kez gerçekleştirilen nükleer denemeler sonucu 190,000 kişi hayatını kaybetmiştir. 1980'li yıllara gelindiğinde ise plânlı doğum politikaları ile Uygur Türklerinin çoğalmalarına mani olunmaya çalışılmıştır. Diğer yandan bölgeye yoğun bir nüfus nakli gerçekleştirilmiş ve doğum politikalarına uymayan kişiler sağlıklı olmayan ortamlarda zorunlu kürtaj operasyonlarına maruz birakılarak Uygur Türklerinin soyu bir kırım girişimi ile karşı karşıya bırakılmıştır. 1999 yılında "go west" politikasıyla bölgeye birçok Hanlı tehcir olunurken, aynı zamanda bölgenin gelişerek istikrarlı bir hale gelmesi için de sübvansiyonlar verilerek orta sınıf bir tüccar grup oluşturmaya çalışılmıştır. 2001-2009 arası dönemde 11 Eylül saldırılarından sonra Pekin, Doğu Türkistan İslami Hareketini (Uygur Türklerini), El-Kaide ve Taliban ile bağlantılı olduğu gerekçesiyle 'terörist' olarak ilan etmiş; bu yeni süreçte Çin ve ABD'nin bölgeye ilişkin algılamalarında 'terörizm'le ilintilendirme etkili olmuştur (Dağc1 ve Keskin, 2013: 15-16; Özönder, 1998: 13; Yinanç, 2012: 8; Avc1, 2012: 8; Zenginoğlu, 2013: 25).

ÇHC, özellikle 11 Eylül olaylarından sonra Doğu Türkistan'daki hak arayışlarını, ayrımcılığa karşı oluşan hareketleri eşitsizlik için yükselen sesleri "ayrılıkçlık, terörizm ve aşırıcılık" olarak sunmaya çalışıp, uyguladığı zulüm ve şiddeti bu şekilde meşru göstermeye çalışmıştır (Doğu Türkistan Vakfı, 2014). Çin'e göre ülke içerisinde ayrılıkçı fikirlere sahip üç grup olduğu belirtilmektedir: Uygurlar, Tibetliler ve Moğollar. Buna rağmen Çin merkezi yönetimi tamamen Uygurlar üzerine yoğunlaşmış ve Uygur Türklerini 'terörist' olarak deklare etmiştir (Zenginoğlu, 2013: 25). Çin'in Uygurlulara karşı kullandığı terörizm söyleminin bir çarpıtmadan ibaret olduğu her halükarda sarih bir şekilde ortadadır. Çünkü Doğu Türkistan halkı, manevi değerlerini koruyabilmenin, özgür bir biçimde dilini kullanmanın, baskı olmadan dinlerini yaşamanın ve gelecek nesillerine kültürlerini bırakmanın haklı mücadelesini dünya kamuoyunun gözleri 
önünde vermektedir. Her toplumda şiddete eğimli insanlar olduğu gibi Uygur halkının içinde de şiddet yanlısı kişiler ya da gruplar bulunabilir. Ama bu Doğu Türkistan halkının 'terörist' olduğunu ya da haklı bir mücadele yürütmediklerini göstermemektedir (Avc1, 2012: 10). Bu durum, hakikat ile bağdaşmamaktadır.

\subsection{Türk-Çin İlişkileri Bağlamında Doğu Türkistan Sorunu}

1990'lı yılların başında SSCB’nin yıkılması ile ortaya çıkan beş bağımsız Türk Devleti beraberinde Doğu Türkistan bölgesine olan ilgiyi arttırmış; bölgede yeni bir Türk devletinin kurulacağı inancını ortaya çıkarmıştır. Türkiye bu noktada yaşadığı uluslararası izolasyondan kurtulma umuduyla bağımsızlı̆ını yeni kazanan bu devletlere büyük ilgi göstermiş, diş dünyada "Pan-Türkist" bir hareket olarak adlandırılan bu durum ise Rusya ve Çin'i büyük ölçüde rahatsız etmiştir (Yinanç, 2012: 10).

Türkiye-ÇHC arasındaki siyasi, ekonomik ve ticari ilişkilerde yaşanan gelişimim genelde Türkiye'nin aleyhine olduğu görülmektedir. Türkiye'nin stratejik konumu, Orta Doğu, Orta Asya ve Kafkasya ile olan bağlantıları, Doğu Türkistanlılarla koparılması güç manevi/tarihsel bağları Türkiye'yi bölgeyle yakından ilgilenmek zorunda bırakmıştır. Bu durum en temelde Türkiye'nin Çin'e değil; Çin'in Türkiye'ye ihtiyacı olduğu gerçeğini gündeme getirmiştir (Karaca, 2007: 242; Şen, 2009: 129; Avcu, 2016).

Türkiye-Çin ilişkilerinin başlangıcı olarak 1925 yılı itibara alınır. 1929 yılında Türkiye Nanking'de ilk diplomatik misyonunu açmıştır. Sonrasında 1940'da Çin, İstanbul' da Konsolosluk açmak için başvurmasıyla ilişkileri bir adım daha ileri götürür (Şen, 2009: 129).

“Kararsız destek dönemi" olarak adlandırılan 1990-1995 yılları arasında Doğu Türkistan sorunu Türk kamuoyu gündemine sık sık gelmiştir. 1991'de Başbakan Demirel, Başbakan Yardımcısı İnönü ile bir kısım siyasi ve milletvekilleri, Çin'in Doğu Türkistan'dakileri asimile etmesine izin vermeyeceklerini ve konuyu uluslararas1 kuruluşlarda gündeme getireceklerini belirtmişlerdir. Bir diğer destek de 1992 yılında İsa Yusuf Alptekin ile görüşen Turgut Özal'dan gelmiştir. Özal, Doğu Türkistan bağımsızlığını desteklediğini belirtmiş ve İstanbul'da bir parka "İsa Yusuf Alptekin"in isminin verilmesini sağlamıştır (Yinanç, 2012: 10; Tuna, 2012: 117).

Çin açısından Türkiye ile ilişkileri geliştirmek oldukça önemli görülmüştür. Türkiye'nin Çin kadar dünya siyasetinde yeri olmasa da jeopolitik açıdan oldukça önemli bir ülkedir. Dolayısıyla Çin'in Avrasya politikalarını yürütebilmesi için Türkiye gibi bölgesel güçlerin desteğini almak zorunda olduğu görülmektedir (Çolakoğlu, 2012: $56)$.

1995 yılında Süleyman Demirel'in yapmış olduğu Çin, Endonezya ve Hong Kong'u kapsayan Asya ziyaretinde Doğu Türkistan sorunu en üst düzeyde ilk defa dile getirilmiştir. Doğu Türkistan sorununun ilk defa resmi olarak ortaya konması ise Nisan 1999' da Çin Halk Kongresi Başkanı Li Peng' in Türkiye ziyareti sırasında gerçekleşmiştir. Bu ziyaretten sonra Li Peng, Çin basınına verdiği röportajda Doğu Türkistan sorununu şu şekilde ifade etmiştir: "Sözde Doğu Türkistan (Dong-tu) sorununun ortaya çıkışı, zamanında Xinjiang'dan (Doğu Türkistan) bir avuç insanların Türkiye'ye kaçarak orada küçük bir grup ayrılıkçı gücü oluşturması ile meydana gelmiştir. Onlar sözde "Doğu Türkistan" adında 
bir devlet kurmayı deklare etmişlerdi. Milli ayrılıkçı faaliyetlerle meşgul olmuş, hatta terör faaliyetleri de sürdürmüşlerdi. Bu nedenle, (bu soruna) Xinjiang'daki milletler dâhil, bütün Çin halkı kesinlikle karşı çıkmaktadır" (Çolakoğlu, 2012: 56; Aktaran Ekrem, 2012: 49). Li Peng'in bu sözlerinde kastettiği kişilerin, Mehmet Emin Buğra, İsa Yusuf Alptekin ve beraberindeki Doğu Türkistanlılar olduğu anlaşılmaktadır.

1996 yılının başından itibaren Türkiye'nin Doğu Türkistan politikasında önemli değişimlere gidilmiştir. Çin Dışişleri Bakanlığı, İsa Yusuf Alptekin adını taşıyan parkın kapatılmasını, Doğu Türkistan bayrağının indirilmesini ve Doğu Türkistan şehitleri Anıtı'nın yıkımını istemiş ve bu isteklerinde olumlu sonuç almışlardır (Yinanç, 2012: 10). 1996 yılından itibaren ise Çin karşıtı Doğu Türkistan kuruluşları hakkında soruşturma açılmış ve aynı yıl içerisinde Türkiye'ye sığınma talebinde bulunan 13 Uygur aydınının ülkeyi terk etmeleri istenmiştir. Ayrıca Türk vatandaşlı̆̆ Uygur'un isteklerine de olumlu cevap verilmemiştir (Yinanç, 2012: 10; Tuna, 2012: 118).

2000'in Nisan ayında Çin Cumhurbaşkanı Jiang Zemin'in gerçekleştirdiği Türkiye ziyaretinin Çinli uzmanlara göre en önemli özelliği, terörizme karşı işbirliği konusunu içeren ilk ortak deklarasyona imza atılmasıdır. (Ayrıca Çince literatürde "Doğu Türkistancılar" teröre eşittir.) Bu çerçevede Ankara-Pekin ilişkileri yeni bir düzleme girmiştir. Diplomatik müzakereler ve anlaşmalardan çıkan genel sonuca bakılırsa, Ankara'nın Çin'den sağlayacağı ekonomik ayrıcalıklar ve uluslararası alanda siyasi destek karşılığında Doğu Türkistan sorununun Pekin lehine değiştiği görülmektedir (Ekrem, 2012: 51; Yinanç, 2012: 10).

Cumhurbaşkanı Abdullah Gül'ün Haziran 2009'daki Çin ziyaretinde ekonomik ve siyasi anlamda birçok konu masaya yatırılmıştır. Bu esnada Gül ve beraberindeki Türk heyetinin Urumçi'den ayrılmasını müteakip Temmuz 2009'da patlak veren Urumçi olayları Türkiye'de büyük etki uyandırmış ve dönemin Başbakanı Recep Tayyip Erdoğan'ın yaşanan olaylar hakkında yaptığı 'soykırım' eleştirileri, Çin tarafından büyük bir tepkiyle karşılanmıştır. Dünyada neredeyse hiçbir ülkeden yeterli ilgiyi görmeyen olay karşısında Türkiye'nin ağır eleştirisine karşılık Çin Dışişleri Bakan Yardımcısı Zhai Jun, Urumçi'de yaşanan olaylar için Başbakan Erdoğan'ın kullanmış olduğu 'katliam, soykırım' gibi ifadeleri 'sorumsuzca açıklamalar' diye nitelendirip Türkiye ile gerginleşen ortamı yumuşatmak istemiştir. Türkiye'nin bu noktadaki temel kaygısı, dünyanın hiçbir ülkesi bu olaya bu denli bir tepki göstermiyorken Türkiye'nin göstermiş olduğu tepki karşısında yalnız kalmak olmuştur (Çolakoğlu, 2012: 59-60; Ekrem, 2012: 52).

Bu kaygı oluştuktan sonra Türk-Çin ilişkilerini yumuşatmak amacıyla Başbakan Erdoğan Zafer Çağlayan'ı özel temsilcisi olarak 30 Ağustos- 2 Eylül 2009 tarihleri arasında Çin'e göndermiştir. Çağlayan ise Çin Başbakanı Wen Jiabao'ya Başbakan Erdoğan'ın; "Türkiye Hükümeti 'Tek Çin' politikasını tanımaktadır ve Çin Halk Cumhuriyeti Hükümeti bütün Çin halkının tek yetkili vekilidir. Türkiye, Çin'in egemenliğine ve toprak bütünlü̆̆̈̈ne zarar veren faaliyetlere izin vermeyecektir. Xinjiang (Doğu Türkistan)'da istikrar, toplumsal uyum ve müreffehin sağlanacă̆ına inanmaktadır" mesajını iletmiştir (Aktaran Ekrem, 2012: 52). 
Daha sonra İtalya'da yapılan G-8 zirvesinden sonra Başbakan Erdoğan, yapmış olduğu eleştirinin arkasında durduğunu; Uygurlara yapılanın bir 'soykırım'ı andırdığını ifade etmiştir. Olayı BM konseyine taşıyacaklarını belirten Başbakan Erdoğan, "Bir taraftan evrensel değerleri tartışacağız, insan haklarını konuşacağız, diğer taraftan bunlara seyirci kalacağız; bu olacak iş değil" diyerek, tepkisini dile getirmiştir (Aktaran Şen, 2009: 132). Akabinde bazı kuruluşlar Çin'i protesto etmiş; Çin malları için boykotlar uygulanmıştır. ÇHC ise bu olayların Çin'in içişlerine ilişkin olduğunu belirterek, diğer ülkelerin istikrarı sağlamak amacıyla yaptıklarını, anlayışla karşılamaları gerektiğini vurgulamıştır. Doğu Türkistan Bölgesi Çin'in yumuşak karnıdır ve diğer ülkelerin Çin'e baskı yapmasının bir aracı haline gelmiştir. Bu bağlamda eğer sorun çözüme kavuşturulmazsa, Türkiye ile Çin arasındaki ikili ilişkilerin etkilenmeye devam edeceği ifade edilebilir (Şen, 2009: 133; Ekrem, 2012: 54). Bununla birlikte Türkiye'nin, Doğu Türkistan konusunda tutarlı bir politika izleyemediği ve farklı dönemlerde izlediği bu "kararsı" politikalarla dengeyi sağlayamadığı belirtilmektedir. Türkiye'nin bu "kararsız" politikaları, kamuoyunca bölgedeki Türklerin azınlık haklarının çiğnenmesine göz yumulduğu şeklinde yorumlanmaktadır (Karaca, 2007: 241).

\section{Küresel Açıdan Şincan Uygur Özerk Bölgesi}

\subsection{Hak İhlalleri}

Son 200 yıldır işgal altında olan Doğu Türkistan 1949 yılından bu yana yoğun bir şekilde insan hakları ihlaline maruz kalmaktadır. İnsan hakları ihlallerinin çoğunun baskıcı siyasetlerden ve Çin hükümetinin resmi politikasından kaynaklandığı görülmektedir. Çin' in büyük bir bölümünün dünyadan 'kopuk' olması, insan haklarıyla ilgili kurumların açık bir şekilde faaliyet göstermesinin yasak olması ve sosyal eylemlerin gereksiz ve acımasız bir şekilde bastırılması, aslında ekonomik anlamda bir dev olan Çin'in, Doğu Türkistan'ın doğal kaynaklarından yararlanıp bölge halkını kargaşa ortamına bırakarak son derece zalim ve emperyalist bir siyaset izlediği görülmektedir (THE, 2016; Balc1, 2013: 22; İHH, 2016). Söz konusu hak ihlallerinden bazıları şu şekilde sıralanabilir:

\subsection{Asimile Politikası ile Çinli Göçü}

Doğu Türkistan'ın en önemli sorunlarından birisi, asimilasyon politikasıyla bölgeye Han Çinlisi yerleştirilmesidir. Böyle bir durumda bölgedeki Uygur nüfusu azalma eğilimi gösterirken, Çinli nüfus artacaktır (Dağcı ve Keskin, 2013: 16; Milli Mefkûre Birliği, 2015). Bölgeye bu denli Çinli nüfusun göçü sonucunda Doğu Türkistan'ın doğal kaynakları adaletsiz bir biçimde Çin ve vatandaşları tarafından kullanılacaktır. Buradaki temel amaç; demografik yapıyı değiştirip bölgeyi tam anlamıyla Çin devletine bağlamaktır. 1949 yılında işgalden önce \% 4 olan Çinli nüfusun yakın bir zamanda \% 50'ye ulaştı̆̆1 görülmektedir (Karaca, 2007: 232; Dağc1 ve Keskin, 2013: 16; THE, 2016). Bu şekilde bir demografik değişiklik/asimilasyon siyaseti, bölgedeki halkı kontrol altına almakla birlikte, gelecekte yapılması muhtemel bir referandumda yeterli sayıya ulaşılması amacı taşıdığı belirtilmektedir (Yinanç, 2012: 9). Kültürleri farklı olan iki toplumun bir arada yaşamasının oldukça zor olduğu söylenebilir. Düzenli bir hijyen ve yemek kültürü bulunmayan Han Çinlisi ile daha muntazam bir hayat tarzına sahip 
Uygur Türklerinin anlaşması ve birbirlerini anlayışla karşılamasının çok zor olacağ söylenebilir (Balc1, 2013: 23).

\subsection{Eğitim ve Dil Politikaları}

Çin yönetimi BM'ye eğitim hakkı konusunda garantiler vermiş ve azınlık dillerinin sistemleştirilmesi hakkında çalışmalar yapmakta olduğunu belirtmiş olsa da söz konusu Doğu Türkistan olduğu zaman Çin'in beyanatlarıyla pratikleri arasında büyük bir uçurum olduğu görülmektedir. Üstelik eğitim konusunda Çin rakamları da gerçeği pek yansitmamaktadır (THE, 2016). Örneğin Şincan Uygur Özerk Bölgesindeki okullarda Uygurca, bir azınlık dili muamelesi görmektedir. Eğitim dili olarak kendi dillerini kullanmakta sıkıntı çeken Uygurların alfabesi ise birkaç kez değişmiştir. Çin, Arapça olan alfabeyi önce Kiril alfabesine; sonra Latin alfabesine ve daha sonra ise tekrar Arapça alfabeye çevirmiştir. 2002 yılından sonra Şincan Uygur Özerk bölgesindeki üniversitelerde de Uygurca yasaklanmıştır (Dağcı ve Keskin, 2013: 22-23).

1980'lere kadar Uygur aileleri çocuklarını hangi okula gönderecekleri konusunda ciddi bir zorluk yaşamışlardır. Çocuklar Uygurca eğitim veren okula gönderilirlerse kültürlerini sürdürebilecek iken, iş bulma ihtimalleri ortadan kalkacaktır. Fakat Çince eğitim veren okula gönderirlerse iş bulmalarında başarılı olma şansının artıp artmadığ 1 da yine bir soru işaretidir. Bu bağlamda 1984 yılı dil politikası bakımından ciddi bir dönüm noktası olmuştur. Han olmayanlar Ortaokulun ikinci sınıfında Çince dersi alırken, bu tarihten sonra ilkokul üçüncü sınıfta, günümüzde ise birinci sınıfta almaya başlamaktadırlar Tamamen kendi kültürlerinden farklı bir şekilde, yatılı eğitim görmektedirler. Dolayısıyla öğrencilerin Çin kültürüyle kaynaşması ve asimile olması kaçınılmaz bir gerçektir (Karaca, 2007: 234; Dağc1 ve Keskin, 2013: 23).

Günümüzde bölgede eğitim dili tamamıla Çince olmuştur. Uygur lehçesinin siyasi, askeri ve idari anlamda yeterli olmadığ gerekçesiyle Uygurca kelimelerin Çince karşılıkları bulunup kullanılması zorunlu hale gelmiştir (Yinanç, 2012: 9). Bölgedeki Han Çinlilerine dilleri ve eğitimleri sayesinde Şincan' daki büyük sanayi işletmelerinde görev verilmektedir. Sözgelimi Şincan'daki Çin Ulusal Petrol Şirketi, çalışanlarının çoğunu Şincan dişından getirmektedir. Bu da bölgedeki Uygur nüfusunun bölge ekonomisi dışına itildiğini (Karaca, 2007: 234) ve bölgede bu nedenle istihdam açığının arttığını göstermektedir.

\subsection{Ekonomi Politikaları ve Çalışma Özgürlüğü}

Doğu Türkistan yerüstü ve yeraltı kaynaklarıyla dünyanın en zengin ülkelerinden biri olmakla birlikte en sefalet içinde yaşayan halklar arasında olduğu da ifade edilebilir (THE, 2016). 1978 yılına kadar Çin'in batı bölgelerinde GSMH'nin büyüme hızı \% 6.4 iken doğu kesimin büyüme hızı \% 6.1 dolayındadır. 1978 yılında Çin, piyasa ekonomisi ve liberal modelde ekonomik reformlara hız vermeye başlamıştır. Bu reformlardan sonra doğu bölgelerinin ekonomik anlamda refaha ulaştığı; batı kesimlerininse ekonomik olarak ciddi bir sorunla karşı karşıya kaldığ1 gözlenmiştir. Yaşanan bu sorunun sebebi, etnik azınlık grupların bulunduğu bölgelerdeki doğal kaynakların büyük sanayi şehirlerine aktarılmasıyla açıklanabilir (Dağcı ve Keskin, 2013: 20; 2016 ). 
Bunun yanında Şincan'ın kurak bir iklime sahip olması sebebiyle sürdürülebilir ekonomik kalkınma için önemli zorluklar yaşamaktadır. Bölgedeki gelir eşitsizliği de dikkate alınması gereken bir başka faktördür. Han nüfusunun fazla olduğu azınlık bölgelerinde meydana gelen ekonomik eşitsizlik, azınlıkların her anlamda dışlanmasını da beraberinde getirmektedir (Dağcı ve Keskin, 2013: 22).

2000 yılında özerk bölgelerin kalkınmasını sağlamak için "Batı Çin'i Kalkındırma” isimli bir program ortaya konulmuştur. Ancak yatırımlarda yine Çin/Han kökenliler istihdam edildiğinden bölge halkı işsiz ve yoksul olarak kalmaya devam etmiştir. Böylece Çinli firmaların kurduğu her yeni fabrika bölgeye yoğun göçü arttırmış; dolayısıyla Uygur şehirlerinde görülen ekonomik refahtan Uygur halkı yoksun kalmıştır (ïHH, 2016 ).

\subsection{Din Hürriyetinin Kisıtlanması}

ÇHC'de Uygurlulara en büyük saldırının İslam'a bağlllıklarından geldiği dile getirilmektedir. 11 Eylül saldırılarından sonra bölgede dini ve inanç yönünden yasaklar artmış; bu durum uluslararası terörizme karşı destek olarak savunulmuştur. 11 Eylül saldırılarını takip eden dönemde din üzerinden Uygur kimliğine ciddi baskı politikaları devreye konulmuştur (Karaca, 2007: 236).

Çin Devleti birçok faaliyetini terörizm ve ayrılıkçı hareketlerle mücadele adı altında bu hareketlerin güvenliğe tehdit oluşturduğu iddiasıyla haklı göstermeye çalışmıştır. Dine yönelik baskılar, şiddetle artış kaydetmiştir. Sadece devlet tarafından onaylanmış Kur'an Kerim nüshaları ve dini sohbetlere izin verildiği gibi, onaylanmamış eserleri ellerinde bulunduranlara karşı da ciddi cezai yaptırımlar uygulanmıştır (Szadziewski, 2013: 31).

Bölgede, Müslümanların asli ibadet yeri olan mescitlerde herkesin ibadet etmesi yasaktır. 18 yaşının altındakilerin camiye girememektedir. Örneğin; devlet memurları, öğrenciler, emekliler ve kadınlar cami sınırları içine girmesi yasak kesimden bazılarıdır (Szadziewski, 2013: 32; İHH, 2016).

Dini değerlerini korumakta zorlanan Uygurlulara 2012 yılının Ramazan ayında ise oruç yasağı getirilmiştir. Mescitlerde kalabalık gruplar halinde ibadet etmek, dini bayramları kutlamak ve uzun dua ibadetleri yapmak da bu kapsamda yasaklanmıştır. İbadet ettiği öğrenilenler ise gözaltına alınıp, para cezalarına çarptırılmaktadır (Dağcı ve Keskin, 2013: 25; THE,2016; İHH, 2016; Milli Mefkûre Birliği, 2015).

Köy memurlarına, "sorumluluk taahhütnamesi" adı altında bir belge imzalatılarak köydeki kadınların hicap ve çarşaf gibi tesettürlü kıyafetleri giymeleri yasaklanmıştır. Bugün dini hassasiyetlerine göre giyinen insanlar küçümsenmekte; hatta halk otobüslerine dahi bindirilmemektedirler (Gökbayrak, 2013: 41-42).

\subsection{Nükleer Denemeler ve Zorunlu Kürtaj}

Çin'in en büyük nükleer merkezi ve deneme alanı Doğu Türkistan bölgesindedir. Çevreyi korumak adına herhangi bir tedbir alınmadan 1994 yılından 1997 yılına kadar 11'i yeraltında olmak üzere; toplam 46 nükleer deneme yapılmıştır. Bu nükleer denemeler sonucunda oluşan sorunlar, insan sağlığının yanında ekolojik dengeyi de tehdit etmektedir. Bu denemelerden kaynaklı olarak halk çeşitli hastalıklara 
yakalanmakta, çocuklar sakat doğmaktadır. Ayrıca Batı ülkeleri Çin'den ithal ettikleri Doğu Türkistan yapımı kuruyemişlerde radyasyon etkileri gördüğünden, Doğu Türkistan kaynaklı malların alımını yasaklamışlardır (Yinanç, 2012: 9; THE, 2016).

Bölgedeki Uygur nüfusunu ciddi boyutta etkileyen bir diğer acımasız ihlal, zorunlu kürtaj uygulamasıdır. Oluşturdukları iskân politikasıyla kendi ülkelerinde azınlık konumuna düşürmeye çalıştıkları bölge halkına şehirde bir, köyde ise iki çocuktan fazlası yasaklanmıştır. Eğer bu sınırlama aşılırsa zorunlu kürtaj uygulaması; oldu ki bebek kız ise de aileler tarafından düşük yaptırılarak öldürülmektedirler. Fakat Uygur Türkleri çok sayıda çocuk yaparak farklı yollardan nüfusuna kaydetmektedirler. Kaydettiremedikleri çocuklar ise yok sayılmakta; doğumlarından haberdar edilmeyen/olunmayan çocuklar evden çıkarılmamakta ve okula ve hastaneye dahi gönderilememektedir. Çin'in diğer bölgelerinde de resmi, bir devlet politikası olarak uygulanan kürtaj ve zorla kısırlaştırma yöntemleriyle çok sayıda anne ve bebek ölmektedir ve hamile kalan kadınların eşleri işten atılmaktadır (THE, 2016; MAZLUMDER, 2010: 62, Milli Mefkûre Birliğii, 2015).

\subsection{Uluslararası Arenada Doğu Türkistan}

Doğu Türkistan konusunun uluslararası ilişkilerde gündeme gelmesi, dünya ülkelerinin Çin ile ekonomik ilişkilerinin tehlikeye girmesi bakımından bir tehdit unsuru olmaktadır. Bu noktada asıl telaşa kapılması Çin olması gerekirken, Çin ile ilişki yapan ülkeler daha çok tedirgin olmaktadır (Kanat, 2013: 19; AGD, 2016). Doğu Türkistan meselesinde bu noktada Çin'in üzerine gitmek, ülkelerin ekonomik çıkarları ile bağdaşmadığından, mesele daha çok sessiz ve tonu 'rahatsız etmeyecek' şekilde dillendirilen bir tepki ile karşılanmaktadır.

Çin, Doğu Türkistan halkına karşı yapmış olduğu insan hakları ihlallerini ve zulmünü gizlemek için uluslararası arenada öne sürdüğü iddialardan birisi de, bölgenin "Çin topraklarının bir parçası olduğu", dolayısıyla da Doğu Türkistan'da yaşananların "Çin'in iç meselesi sayılması gerektiği" yönündedir (Tanay,2016; Milli Mefkûre Birliğii, 2015). Çin, uluslararası toplumun bu meseleye dahlini, uluslararası hukukça kendi içişlerine bir müdahale olarak görmektedir.

Dünya kamuoyu ve uluslararası güçler, Çin'de yaşayan insanların, ülkeleri zorbalıkla ve zulümle hâkimiyet altına alınmaya çalışılan milletten oluştuğunu bildiği halde herhangi bir reel çözüm üretmemektedir. (THE, 2016 ). Olayların yeterince ses bulamasının nedenleri arasında Çin yönetimi tarafından usta bir şekilde gerçekleştirilen sansürleme faaliyetlerinin de etkisi vardır. Bunun yanında Doğu Türkistan sınırında bulunan devletlerin de bu faaliyete katkıda bulunması ortaya daha sorunlu bir durum çıkarmaktadır. Özellikle sosyal medya ortamında yapılan haberleşmeler sıkı kontrol altında tutulmaktadır (Kanat, 2013: 17-18).

Dünyanın barış ve huzurunu sağlamakla yükümlü olarak ihdas edilen Uluslararası Örgütler, çok acı bir şekilde varlık sebeplerine aykırı olarak Doğu Türkistan meselesini görmezden gelmekteler. Bu örgütlerden biri olan BM, her şeye rağmen insanlığın umut bağlamak istediği bir örgüt konumundadır; fakat BM Güvenlik Konseyi'nde Çin' in veto yetkisinin bulunması, gereken ilginin gösterilmesine mani bir durum oluşturmaktadır (ïHH, 2016; THE, 2016). 
BM yetkililerinin bölgeyi ziyaret etmek için bulunulan girişimlere Pekin yönetiminin olumsuz yanıt verdiğini bilinmektedir (Akşam, 2016). Bu endişesini açık bir şekilde ifade eden BM İnsan Hakları Yüksek Komiseri Pillay, Doğu Türkistan bölgesinde meydana gelen olaylarda can kaybı olmasından endişe duyduğunu ve Çinli yetkililerin, şiddetin daha fazla yayılmasını engellemek için yol aramalarını ve aynı zamanda barışçıl gösterilerin yapılmasına izin verilmesi gerektiğinin altını çizmiştir (Şen, 2009: 110).

Çin'in Doğu Türkistan bölgesinde yürüttüğü toptan yok etme politikası gün geçtikçe şiddetini arttırmaktadır. ABD başta olmak üzere diğer ülkelerin de bu politikaları engelleyecek, halk üzerindeki baskı ve şiddeti azaltacak bir faaliyette bulunmadığ tamamıyla çıkar ilişkisi çerçevesinden bakmaktadır. Salt demokrasi ve insan haklarını dile getirmek Doğu Türkistan sorununu çözmemektedir. ABD, İsrail ve Yahudileri korumaktaki hassasiyetini Doğu Türkistan için göstermemesi (Sezer, 2016), Amerikan'ın kurucu idealleri ile hiç de bağdaşmamaktadır. Tabi ki Washington yönetiminin Pekin yönetimini tamamen kaybetmek istememesi de hatırlanmalıdır. Dolayısıyla siyasi ve ekonomik kaygılar sebebiyle Pekin karşısında uygulamaya koyulabilecek seçenekler genelde masada kalmaya devam etmektedir (Şen, 2009: 111).

$A B$ 'nin tutumu değerlendirilecek olursa, ilgili zaman diliminde $\mathrm{AB}$ dönem başkanı İsveç, bölgede yaşanan olaylara tepki göstererek bölgedeki olaylardan "derin endişe ve üzüntü duyduğunu ve olayları esefle kınadığını" belirtilmiş; yaptığı açıklamada taraflara sakin olunması gerektiği konusunda çağrılarda bulunarak bölgedeki gelişmelerin yakından takip edildiğini belirtilmiştir (Şen, 2009: 111). Dönemin İslam Konferansı Örgütü (İKÖ) Genel Sekreteri Ekmeleddin İhsanoğlu ise Çin'in herkes için oldukça önemli olduğunu belirtmiş; bölgedeki sivil kaybın fazla olmasından dolayı derin üzüntü duyduğunu ve sorunun insan hakları bağlamında ele alınması gerektiğini vurgulamıştır (İslam Portalı, 2016). Ayrıca Rusya 5 Temmuz olaylarından sonra Çin'i diplomatik olarak kınamıştır. Uygur sorununun Çin'in içişleri olduğunu belirtmekle birlikte, Çinli yetkililerin hukuk sınırları içinde alacağı tedbirler ile durumun düzeltilmesini ümit ettiğini ifade etmiştir (Şen, 2009: 111-112). Tüketici dernekleri gibi bazı sivil toplum kuruluşları ise Çin'deki gelişmeleri protesto etmiştir. Sonuç olarak; birçok farklı aktör ve kesimden soruna ilişkin tepki gelmesine rağmen, son tahlilde nihai bir çözüme ulaşılamadığı çok açık bir şekilde söylenebilir.

\section{Sorunun Çözümü İçin Öneriler}

Doğu Türkistan meselesi insanlığın en acı gerçeklerinden birisi olarak karşımızda durmaktadır. Çünkü şiddetli bir baskı, işsizlik, eğitim olanaklarından yoksunluk, esaret içinde bırakılmak ve bir yok edilme tehlikesi altında yaşamakla yüz yüzedir. Bugün soyu ve kültürü tehlikede altındaki Doğu Türkistan'ın insan haklarından yararlanmasının (Öksüz, 1998: 32-33) önündeki olanaklar kaldırılmıştır.

Doğu Türkistan meselesi insani bir sorun olduğu için Çin'in bölgedeki uluslararası sivil gözlemcilere ortam hazırlaması gerekmektedir. Çin yönetimi asimile politikasından vazgeçmeli; demografik yapının değişmesi için yapılmakta olan nüfus hareketlerini (tehciri) durdurmalıdır. Çin'in bölgedeki insan hakları ihlaline kayıtsız şartsız bir şekilde son vermesi gerekmektedir. Basın ve ifade özgürlügünün önündeki engellerin aciliyet 
arz etmektedir. Bölgede uygulanan her türlü ekonomik ayrıcalığa son verilmelidir. Kürtaj ve benzeri uygulamalar kaldırılmalı ve olumsuz sonuçlar doğurmakta olan nükleer denemelere son verilmelidir. Türkiye ise dış politikasını yeniden gözden geçirmeli ve Uygurların durumunu dış politika önceliği olarak görmelidir. Türkiye Doğu Türkistan hakkındaki tavrını, Uygur Türkleri lehine çevirmeli; aynı zamanda Doğu Türkistan meselesinin önemini en üst sıralara taşımalıdır. Uluslararası toplumları, BM başta olmak üzere; insan haklarının önemini her fırsatta dile getiren uluslar-üstü ve arası kuruluşların Doğu Türkistan hakkında daha duyarlı olması gerekmektedir. Uluslararası gözlemciler tarafından yeni bir nüfus sayımı yapılmalı ve Doğu Türkistan nüfusu kesin bir şekilde belirlenmelidir (Bk. MAZLUMDER, 2010: 7173; Öksüz, 1998: 33; İHH, 2016; Milli Mefkûre Birliği, 2015).

\section{Sonuç}

Yüzyıllar boyunca Uygur Türklerine ait olan Doğu Türkistan artık Çin'e bağlı Şincan Uygur Özerk Bölgesi olarak tarihe kaydedilmiştir. Ancak burada altı çizilmesi gerekli temel nokta; bölgenin "Şincan" değil, “Doğu Türkistan” olduğudur. Meseleyi böyle ele almak ve bölgede verilen mücadelelere karşı saygı göstermek bakımından "Doğu Türkistan" ifadesi, daha doğru bir anlatımdır.

Ekonomik anlamda gelişmiş olan Çin'in, ülke içinde göç etmek isteyen vatandaşları için yeni yerleşim alanları bulmak zorunda kalması, Doğu Türkistan nüfusunu Han Çinlileri lehine dengelemek istemesi, zengin topraklarıyla bölgeyi bu göçmenler için yeni yaşam alanı haline getirmiştir. Nüfusu günden güne eriyen ve gerileyen Uygur Türkleri, bölgenin ekonomik imkânlarından Han Çinlileri kadar yeterince yararlanamamaktadir.

Tarih boyunca sürekli mücadele veren ve sömürülen Uygur Halk1, insan hakları ihlalini en ciddi biçimde yaşayan topluluklardan birisidir. Doğu Türkistan halkının problemleri ne Filistin-İsrail meselesinde ezilen Müslümanlar ne de AzerbaycanErmenistan sorununda mağdur olan Türkler kadar dile getirilmemektedir. Çin'in büyüyen ekonomisi ve Türkiye ve diğer ülkelerin bu temelde gerçekleştirdiği ilişkiler, Doğu Türkistan sorununun yeterince gündeme gelmesinin önünde bir engel olarak durmaktadır.

Diğer bir ifadeyle siyasi ve ekonomik ilişkiler, temel insan haklarının kullanımının engellenmesinde sürekliliğin olduğu ve zaman zaman 'insanlık trajedisi' niteliğine varan hak ihlallerinin yaşandığı meselenin önüne geçmiş durumdadır. Bugün gelinen noktada Uygur halkının dinlerini ve hürriyetlerini savunmak için düzenledikleri girişimler çok sert bir şekilde bastırılmakta, birçok Uygur Türkü, insan haklarına aykırı bir biçimde idam edilmektedir. Türkiye'nin böylesi bir sorunu insani olarak görmesi dahi Çin'e dair konuyla ilgili izlenen dış politikaların değişmesine ve esnemesine yardımcı olabileceği mülahaza edilmektedir.

Türkiye bu konuda gücünü göstermeli ve bu zulmün durması için Çin'e baskı yapmalıdır. Doğu Türkistan sorununa koymuş olduğu tepki, söylem düzeyinden fiiliyata geçirilmeli ve 'yaraya merhem' olacak bir şekle getirilmelidir. Türkiye Uygur Türklerinin sesi olmalı ve kendisine olan tarihsel ve stratejik güveni boşa çıkarmamalıdır. Bugün AB ve ABD gibi Çin'le ticari, siyasi ve ekonomik çıkarları olan 
ülkelerin mesele hakkındaki Çin aleyhine yaklaşımları geçici niteliktedir. Fakat dini, vicdani ve milli yakınlı̆̆ı nedeniyle müdahil olması gereken ülkemiz açısından bu soruna sert ve dik bir duruş göstermek bir borçtur, vebaldir.

29 Nisan 1951 yılında Urumçi'de şehit edilen Osman Batur'un söylediğini bir kez daha hatırlamakta fayda var: "Ben ölebilirim ama dünya durdukça benim milletim istiklal mücadelesine devam edecektir." Uygur Halkı mücadelesine her halükarda devam edecektir. Fakat bu, Türkiye'nin elinden gelenin en iyisini yapmasına mani değil. Zira bu sorun, sadece Uygur halkının sorunu değil; tüm insanlığın kanayan bir yarasıdır.

\section{Kaynakça}

AKŞAM GAZETESİ (2006), BM Doğu Türkistan Zulmünü Hatırladı (2015). http://www.aksam.com.tr/dunya/bm-dogu-turkistan-zulmunu-hatirladi/haber389140, (Erişim Tarihi: 04. 03. 2016).

AVCI Erkan (2012). "Doğu Türkistan Sorunu", Kocaeli Üniversitesi Sosyal Bilimler Enstitüsü, Uluslararası İlişkiler Anabilim Dalı, Ödev Danışmanı: Yrd. Doç. Dr. Buket Önal, Kocaeli 2012.

AVCU Tülin (2015). “Doğu Türkistan Sorunu ve Perde Arkası", http://politikaakademisi.org/2015/07/19/dogu-turkistan-sorunu-ve-perdearkasi, (Erişim Tarihi: 08.03.2016)

AYNURAL, S., KESİCI, A. Kayyum (2005). "Batı Türkistan Cumhuriyetleri Birliğinin Gerekliliği", Sosyal Siyaset Konferansları Dergisi, Sayı: 50, s.1211-1230.

BALCI, Aslan (2013). “Doğu Türkistan'daki Çin Katliamı”. Gökbayrak Dergisi, Yıl: 20, Say1: 111, s. 22-24.

ÇOLAKOĞLU, Selçuk (2012). “Türkiye-Çin İlişkileri: Tek Taraflı Aşk Mi?” Ortadoğu Analiz, Cilt: 4, Sayı: 45, s. 53-66.

DAĞCI, K., KESKİN, M. (2007). “Çin'in Doğu Türkistan Politikası ve Azınlık Hakları Bağlamında Hak İhlalleri”, Barış Araştırmaları ve Çatışma Çözümleri Dergisi, Cilt:1, Say1: 2, http://dergi.cicr.yalova.edu.tr/article/view/5000067303, (Erişim Tarihi: 03.12.2016).

DELİ, Y. Emre (2015). "Yeni Başlayanlar İçin Doğu Türkistan Sorunu" http://www.beyaztarih.com/makale/yeni-baslayanlar-icin-dogu-turkistansorunu, (Erişim Tarihi: 04.03.2016).

Doğu Türkistan Sorunu Nedir? (2009), http://the.org.tr/2009/10/13/dogu-turkistansorunu-nedir, (Erişim Tarihi: 11.03.2016).

DOĞU TÜRKİSTAN, http://www.agd.org.tr/dogu-turkistan.html, (Erişim Tarihi: 13.03.2016)

DOĞU TÜRKİSTAN VAKFI, http://www.dtv.org.tr/?HABER/110/dogu-turkistan-vakfi2014-dogu-turkistanda-insan-haklari-raporu.html 29/12/2014, (Erişim Tarihi: 10.10.2016).

ERKIN, Ekrem (2012). “Türkiye-Çin İlişkilerinin 40 Yılı (19712011)", http://www.sde.org.tr/tr/newsdetail/turkiye-cin-iliskilerinin-40-yili-19712011-raporu/2902, (Erişim Tarihi: 04.03.2016).

ERKIN, Ekrem (2011), Çin'in Orta Asya Politikaları, (Ed.) Murat Yıldız, SFN Televizyon Tasarım Tanıtım Yayıncılık, Ankara. 
GÜL, Osman Kubilay (2007). “Doğu Türkistan'dan Türkiye'ye Hazin Bir Göç Hikâyesi", Turkish Studies, Cilt:2, Sayı:1, s.252-273, http://www.gokbayrak.com/sayfa.asp?id=94, (Erişim Tarihi: 07. 03. 2016)

HAYİT, Baymirza (2004). Milli Türkistan Hürriyet Davası, Ankara: Atatürk Kültür Merkezi Yayınları.

İHH İNSANI YARDIM VAKFI (2015). İHH'dan Doğu Türkistan Raporu, http://www.ihh.org.tr/tr/main/news/0/ihhdan-dogu-turkistanraporu/2905, (Erişim Tarihi: 07.03.2016).

İGMG (2016), “İKÖ: Doğu Türkistan'da Yaşananlar Dialogla Çözülmeli, (2009)", http://www.igmg.org/tr/haberler/yazi/ikoe-dogu-tuerkistanda-yasananlardialogla-coezuelmeli.html, (Erişim Tarihi: 14.03.2016).

KANAT, K. Buğra (2013). “Uygurlarda Umutsuzluk ve Rejime Karşı Yabancılaşma Var", Gökbayrak Dergisi. Y11: 20, Sayı: 113, s.15-20.

KARACA, R. Kutay (2007). “Türkiye-Çin Halk Cumhuriyeti İlişkilerinde Doğu Türkistan Sorunu," Akademik Bakış, Cilt: 1, Sayı: 1, s.219-245.

MAZLUMDER (2010). Doğu Türkistan Insan Hakları Raporu 2010, http://konya.mazlumder.org/fotograf/yayinresimleri/dokuman/doguturkistan-raporu.pdf, MAZLUMDER, (Erişim Tarihi: 09.10.2016).

MILLİ MEFKÛRE BİRLİĞİ (2015). Doğu Türkistan Raporu, http://www.turkyurduhaber.org/haber/14025/milli-mefkure-birliginden-doguturkistan-raporu.html, (Erişim tarihi: 10.10.2016).

ÖKSÜZ, Enis (1998). "Konuşma”, İçinde, Doğu Türkistan'da Çin'in Sömürge Politikası, (Ed.) Yücel Hacaloğlu, Ankara: Türk Yurdu Yayınları.

ÖZÖNDER, Cihat, (1998). “Doğu Türkistan'ın Resmi Çin Sömürgesi Haline Gelişi”, İçinde, Doğu Türkistan'da Çin'in Sömürge Politikası, (Ed.) Yücel Hacaloğlu, Ankara: Türk Yurdu Yayınları.

SEZER, A. Ahmet (2012). 'Türkiye'nin Bir Doğu Türkistan Politikası Yok', http://www.dunyabulteni.net/?aType=haber\&ArticleID=217332, (Erişim Tarihi: 14.03.2016).

SZADZIEWSKİ, Henryk (2013). “Doğu Türkistan'daki Uygurlara Uygulanan Dini Baskı", Gökbayrak Dergisi, Y1l: 20, Sayı: 111, s.30-32.

ŞEN, Fatih (2009). “Çin'in Şincan-Doğu Türkistan Sorunu: Dünü, Bugünü, Geleceği", Ortadoğu Analiz, Cilt: 1, Sayı: 7-8, s.124-134.

ŞEN, Fatih (2009). "Uluslararası Tepkiler Açısından Şincan Uygur Sorunu”, Ortadoğu Analiz, Cilt: 1, Sayı: 9, s.107-115.

TANAY, Yücel (2014). “Doğu Türkistan'ın Demografik Yapısı ve Çin'in Gizlediği Gerçekler" http://www.oncevatan.com.tr/dogu-turkistanin-demografik-yapisi-vecinin-gizledigi-gercekler-makale,32047.html, (Erişim Tarihi: 07.03.2016).

TANAY, Yücel (2016). “Doğu Türkistan Asla Çin Toprağ1 Değildir." http://www.uyghurcongress.org/tr/?p=12793, (Erişim Tarihi: 13. 03. 2016).

TOGAN, Zeki Velidi (1981). Umumi Türk Tarihi'ne Giriş, İstanbul: Enderun Kitabevi.

YİNANÇ, Refet (2012). “Türkiye-Çin Halk Cumhuriyeti Olası Meseleler”, Gökbayrak Dergisi, Y1l. 19, Sayı. 108, s. 8-13.

ZENGINOĞLU, Samet (2013), “Doğu Türkistan'ı Unutmamak”, Gökbayrak Dergisi, Yıl: 20, Sayı: 113 , s. $21-45$. 